\title{
Political Competition and Financial Stability in the Developing World
}

\author{
Choe, Wongi \\ (Institute of Foreign Affairs and National Security)
}

\section{$\langle$ CONTENTS〉}

I. Introduction

II. Domestic Politics and Economic Policy Outcomes

III. Banking Regulation and Financial Stability

IV. Hypotheses

V. Data and Methodology
1. Dependent Variable

2. Independent Variables

3. Control Variables

4. Methodology

VI. Results

VII. Concluding Remarks

- Keyword: political competition, financial liberalization, financial stability, developing countries

\section{【ABSTRACT】}

This paper examines the ways in which electoral competition and institutional distribution of veto players in domestic politics influence the robustness of banking regulation and financial stability in developing world. I conduct a cross-section time-series multivariate logistic regression on a banking crisis data set for 60 developing countries from 1974 through 1997. Using outbreak of banking crisis as a measure of the robustness of banking regulations, I examine how political institutional variables affect the likelihood of outbreak of banking crisis in developing world. I find that greater electoral competition is associated with less likelihood of banking crisis. I also find that the most dominant argument in the field of market reform that centralized decision making is most conducive for market reform is not significant in the case of banking regulation. These findings have broad implications for research on the political determinants of policy outcomes in general and financial reform in particular. 


\section{I . Introduction}

Under what political conditions do governments in developing countries adopt prudent financial regulations that limit imprudent financial activities of domestic banks? Does greater electoral competition in contests for political office increase or reduce the governments' willingness to adopt prudent financial regulation in developing countries? Is the presence of multiple veto players in domestic politics conducive or detrimental to establishing robust financial regulations in developing countries? In short, in what ways do domestic political and institutional factors shape the financial regulations in developing world?

〈Figure 1〉 Systemic Banking Crisis in Developing World, 1974-1998

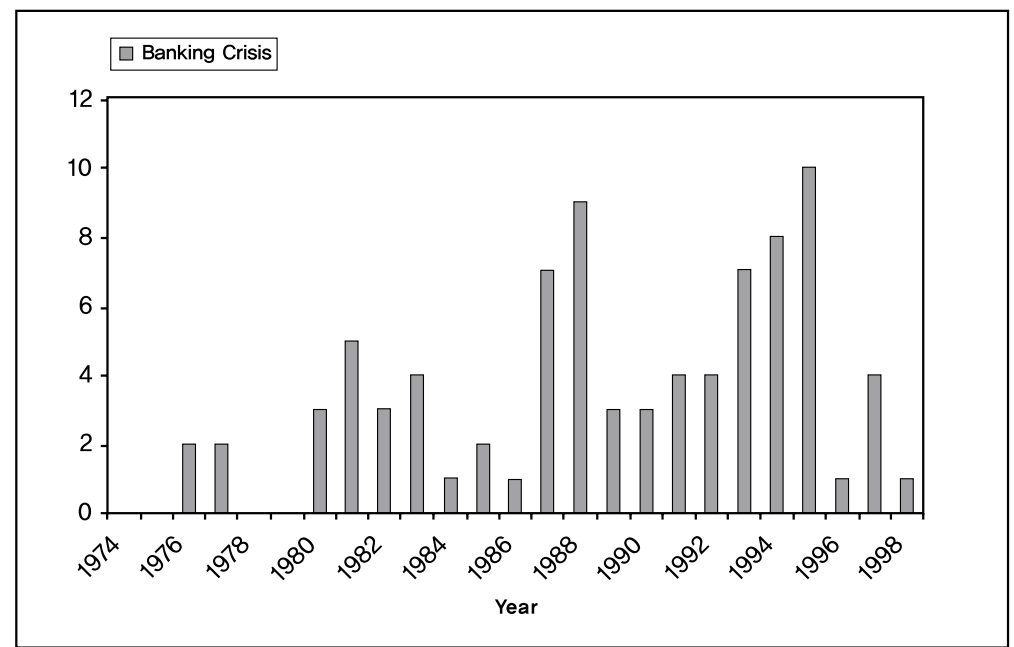

Source: Caprio and Klingebiel (2001): Note that the figure does not include non-systemic "borderline crises" and systemic banking crises of post-communist countries.

Given the increased frequency with which financial crises outbreak around the developing world in the 1990s as we can see in Figure 1, scholars have pointed out that under an open capital account regime, countries that have imprudent financial regulations, that is, low transparency, absence of effective banking laws, prevalence of supervisory forbearance, and practices of politically motivated bailout of imprudent banks, were particularly vulnerable to exogenous shocks like sudden reversal of capital flows. ${ }^{1)}$ In most instances of recent financial crises politically distorted management of

1) Liliana Rojas-Suárez and Steven R. Weisbrod, "Banking Crises in Latin America: Experiences and Issues," in Ricardo Hausman and Liliana Rojas-Suárez (eds.), Banking Crises in Latin America (Washington D.C.: Inter-American Development Bank, 1996); Gerard Caprio and Daniela Kingebiel, 
financial regulation was the main factor that aggravated problems associated with bank insolvencies. ${ }^{2}$

While there is little disagreement about the critical role of political institutional factors in influencing the formation of financial regulation, and the outbreak of financial crises for that matter, it is surprising that we know so little about the causal relationship between domestic political factors and financial regulation and stability in the developing world. While econometric studies by economists do investigate the causes of currency and financial crises, they mostly focus on the role of macroeconomic and international economic factors, sidestepping the causal role of domestic political and institutional factors. A few existing works by political scientists, mostly country-specific case studies motivated by financial meltdown of Asian countries in 1997, focus squarely on the governments' policy response to imminent outbreak of financial crises and do not seriously consider the structural relationship between political factors, and financial regulation and financial stability. In short, the literature lacks rigorous empirical research that would provide a systemic investigation of political determinants of financial sector regulation and stability across developing world. ${ }^{3)}$

"Bank Insolvencies: Cross-country Experiences," World Bank, World Bank Policy Research Paper 1620 (Washington D.C., 1996); Reuven Glick and Michael Hutchison, "Banking and Currency Crises: How Common Are Twins?" Unpublished manuscript, Federal Reserve Bank of San Francisco and University of California (Santa Cruz, 2000); Mansoob S. Murshed, and Djono Subagjo, "Prudential Regulation of Banks in Less Developed Economies," World Institute for Development Economics Research, Working Paper No.1999, United Nations University, 2000; Asli Demirgüç-Kunt and Enrica Detragiache, "Financial Liberalization and Financial Fragility," in Gerard Caprio, Parick Honohan and Joseph E. Stiglitz, Financial Liberalization: How Far, How Fast? (N.Y.: Cambridge University Press, 2001); Barry Eichengreen and Carlos Arteta, "Banking Crises in Emerging Markets: Prosumptions and Evidence," in Mario I. Blejaer and Marko Skreb (ed.), Financial Policies in Emerging Markets (Cambridge: The MIT Press, 2002).

2) T. J. Pempel (ed), The Politics of the Asian Economic Crisis (Ithaca: Cornell University Press, 1999); Gregory W. Noble and John Ravenhill (eds.), The Asian Financial Crisis and the Architecture of Global Finance (N.Y.: Cambridge University Press, 2000); Stephan Haggard and Andrew MacIntyre, "The Political Economy of the Asian Financial Crisis: Korea and Thailand Compared," Gregory W. Noble and John Ravenhill (eds), The Asian Financial Crisis and the Architecture of Global Finance (New York: Cambridge University Press, 2000); Martin Brownbridge and Colin Kirkpatrick, "Financial Regulation in Developing Countries," Journal of Developmental Studies, 37(1) (2000); Stephan Haggard, The Political Economy of Asian Financial Crisis (Washington D.C.: Institute for International Economics, 2000); Andrew MacIntyre, "Institutions and Investors: The Politics of Economic Crisis in Southeast Asia," International Organization, 55(1), 2001, pp.81-122.

3) An important exception is a recent work by Philip Keefer (2002) which examines the impact of checks and balances on financial stability of sixty five developed and developing countries for the period of 1980-1994. Also, there are a few large-N research works on the role of political factors in shaping exchange rate policies (Bernhard and Leblang 1999), currency crises (Leblang 2002) and monetary policies (Keefer and Stasavage 2002; Hallerberg 2002), but none of which exclusively focus on the financial regulation and stability of developing countries. 
This paper is designed to fill this gap in the literature, and provides an empirical analysis of the role of political factors in the formation of financial regulations and the outbreak of financial crises. I specifically examine the role of electoral competition, party system fragmentation, and institutional distribution of veto players in affecting the robustness of financial regulation and stability on a sample of 60 developing countries. The theoretical expectation about the role of these political variables in shaping financial regulation in the literature is ambiguous. On the one hand, some scholars argue that low level of political competition through centralized decision making would be conducive for effective policy outcomes and market reform. The prediction from this perspective is a positive relationship between centralization and robust banking regulation and financial stability in developing world. On the other hand, others suggest an opposite argument, contending that it is political competition via decentralization that is more facilitative for policy performance and market reform. The extension of this perspective to banking regulation would be a negative relationship between centralization and robust prudential regulation. Using logistic regression method, I examine how political institutional variables affect the likelihood of banking crisis and robustness of banking regulation in developing countries.

Empirical test suggests following three points. First, contrary to the mainstream perspectives on the politics of economic reform, I find greater electoral competition, for the executive as well as the legislature, is associated with lower probability of banking crisis and hence greater financial stability. It indicates that countries with higher degree of electoral competition are more likely to have a robust banking regulation. Second, I do not find any significant relationship between institutional distribution of veto players and the robustness of financial regulation. Finally, party fragmentation does not have any significant influence on the probability of banking crisis. My finding suggests that competitive political environment facilitates robust financial regulation and contributes to maintaining financial stability in the developing world.

In the remainder of the paper, I review the extant literature, develop hypotheses, and test them. The first section of the paper provides a brief overview of the extant perspectives focusing on the role of electoral competition and institutional distribution of veto players. The second section develops hypotheses relating political competition and institutions to banking regulations, and banking crises. The third section details the data set and empirical strategy, and the fourth section interprets and discusses the results. The final section concludes. 


\section{Domestic Politics and Economic Policy Outcomes}

Political economy literature has viewed government economic policies as an outcome of political choices not only constrained by institutional arrangements of political governance but also affected by interests of electoral constituencies. ${ }^{4}$ Especially, the political incentives and constraints generated by political institutions such as electoral rules and institutional separation of power are considered critical factors for the politicians' policy choices. Emphasis on the role of the political and institutional factors has been particularly salient among the scholars working on the economic reform of developing countries. ${ }^{5}$

The conventional wisdom advanced by mainstream scholars working on developing world emphasizes "political autonomy" of the reform-minded executive as an essential institutional prerequisite to overcome political impediments inherent in market reform. ${ }^{6}$ The logic of distributional conflicts has been the central theoretical construct upon which major arguments over issues of economic reform have formed. ${ }^{7)}$ For example, Fernández and Rodrik contend that conflicts of individual interest groups over the issue of sharing the costs of reform were at the heart of resistance that generates the "status quo bias" in market reform process. ${ }^{8)}$ The traditional view that authoritarianism is more conducive to economic adjustment than democratic government is also largely based on the assumption that the coercive nature of authoritarian regime is an advantage in coping with distributional conflicts. ${ }^{9)}$

4) Peter Gourevitch, "Squaring the Circle: The Domestic Sources of International Cooperation," International Organization 50(2), 1996, pp.349-373; Geoffrey Garrett and Peter Lange, "Internationalization, Institutions and Political Change," in Robert O. Keohane and Helen V. Milner (ed.), Internationalization and Domestic Politics (N.Y.: Cambridge University Press), pp.48-55; Mancur Olson, The Logic of Collective Action (Cambridge, Mass: Harvard University Press, 1965).

5) For a review of the literature on market reform, see Mariano Tommasi and Andrés Velasco, "Where Are We in the Political Economy of Policy Reform," Policy Reform 1, 1996, pp.187-238; Stephan Haggard, "Interests, Institutions and Policy Reform," in Ann O. Krueger (ed.), Economic Policy Reform: The Second Stage (Chicago: University of Chicago Press, 2000), pp.21-57.

6) Adam Przeworski, Democracy and the Market: Political and Economic Reforms in Eastern Europe (N.Y.: Cambridge University Press, 1991); Joan M. Nelson, "The Politics of Economic Transformation : Is Third World Experience Relevant in Eastern Europe?" World Politics 45(3), 1993, pp.433-463; Stephan Haggard and Robert Kaufman, The Political Economy of Democratic Transitions (Princeton: Princeton University Press, 1995).

7) Joel S. Hellman, "Winners Take All: The Politics of Partial Reform in Postcommunist Transitions," World Politics 50(2), 1998, pp.206-208.

8) Raquel Fernández and Dani Rodrik, "Resistance to Reform: Status Quo Bias in the Presence of Individual-Specific Uncertainty," in Federico Stuzenegger and Mariano Tommasi (ed.), The Political Economy of Reform (Cambridge, Mass.: MIT Press, 1998), pp.61-76.

9) Thomas Skidmore, "The Politics of Stabilization in Postwar Latin America," in James Malloy (ed.), 
In this perspective greater political competition in the form of broad political participation of diverse social forces and activation of legislative politics render reformers vulnerable to electoral backlash by those social actors whose economic interests are undermined by market reform. Heightened political competition and distribution of veto power over multiple political actors are likely to result in partisan fragmentation and polarization, executive immobilism, and legislative gridlock that ultimately narrow political support basis for reformers. This line of research suggests at least three distinctive advantages of centralized decision making in producing positive policy outcomes in the developing world context. ${ }^{10)}$

First, centralized institutional arrangement lowers intra-governmental bargaining costs and helps resolve collective action problem in reform process. Market reform often requires drastic overhaul of existing policy regime, and the existence of multiple veto gates would make it costlier to initiate policy changes. For example, Haggard and Kaufman in their influential study comparing the economic performance of newly democratized developing countries, argue that countries with fragmented party system would have difficulty in generating legislative support for economic reform policies since proliferation of political parties brings diverse, often conflicting, interests into the policy process. ${ }^{11}$ They show that countries with legislature in which multiple political parties exert effective veto power on the executive suffered greater setbacks in market oriented reform and economic performance. They contend that "centralized executive authority plays a pivotal role in overcoming the collective action problems and distributional conflicts associated with the initiation of comprehensive economic reforms." ${ }^{22}$

Second, centralization of decision making helps the government to come up with timely policy adjustment. Alesina and Drazen argue that the delay of economic stabilization such as fiscal adjustment is the outcome of "war of attrition" in which different groups attempt to dump the costs of economic adjustment onto other groups. ${ }^{13)}$ Haggard and MacIntyre point out that fragmentation of legislature due to multi-party system in

Authoritarianism and Corporatism in Latin America (Pittsburgh: University of Pittsburgh Press, 1977); Stephan Haggard and Robert Kaufman, "Economic Adjustment in New Democracies," in Joan M. Nelson (ed.), Fragile Coalitions: The Politics of Economic Adjustment (Washington D.C.: Overseas Development Council, 1989), pp.57-77.

10) In this paper, 'centralized decision making' refers to either each, or combination of, lower level of electoral pressure on the incumbent politicians, fewer number of institutional veto players in the policy making process, and party system that is not fragmented and polarized.

11) Haggard and Kaufmann (1995).

12) Ibid., p.163.

13) Alberto Alesina and Allan Drazen, "Why are Stabilization Delayed?" in Federico Sturzenegger and Mariano Tommasi (ed.), The Political Economy of Reform (Cambridge, Mass: The MIT Press, 1998), pp.77-103. 
Thailand was one of the main factors responsible for the delay in proper policy responses to the plummeting exchange rates that contributed to the complication of the crises in $1997 .{ }^{14)}$

Finally, centralization helps to extend time horizons of decision makers. To the extent that reformers are vulnerable to electoral backlashes or challenge of political opponents, their policies would be dominated by short-term political calculations. ${ }^{15)}$ For example, Kessler shows how electoral imperative distorted the ways in which the Mexican government pursued privatization of nationalized banks in the early $1990{ }^{16}{ }^{16}$ In order to stay afloat against the heightened electoral challenge of the opposition parties, it was imperative for the Institutional Revolutionary Party (PRI, Partido Revolucionario Institucional) to expand its electoral constituency and reach out to groups that were traditionally outside its electoral support basis. While the privatization was pursued under the rubric of economic liberalization and facilitation of freer markets in Mexican financial sector, the Mexican government not only strictly prohibited foreign acquisition of Mexican financial sector, but also imposed a heavy protective barrier for the privatized banks. By guaranteeing monopolistic profits through protection both from the potential foreign and domestic competitors, Salinas used privatization as a tool for mobilizing allegiance from financial-industrial elite who were not traditionally tied to the party. The revenues collected from the privatization provided the PRI with a useful source of "political capital" that was used to finance the PRONASOL, a politically motivated massive anti-poverty program that targeted urban poor and Indians for their electoral support.

On the other hand, another strand of literature suggests a quite opposite prediction, pointing out policy distortions and economic inefficiencies generated by political concentration and the virtues of decentralized decision making for economic outcomes. ${ }^{17}$ In this perspective decentralized decision making, that is, competitive electoral pressures, institutional checks and balances, and multiple veto gates, prevents ruling politicians'

14) Haggard and MacIntyre (2000).

15) Alberto Alesina and Nouriel Roubini with Gerald D. Cohen, Political Cycles and the Macroeconomy (Cambridge, Mass: The MIT Press, 1999).

16) Timothy P. Kessler, "Political Capital: Mexican Financial Policy Under Salinas," Word Politics 51(1), 1998, pp.36-66.

17) Avinash Dixit and John Londregan, "Redistributive Politics and Economic Efficiency," American Political Science Review 89(4), 1995, pp.856-866; Avinash Dixit and John Londregan, "The Determinants of Success of Special Interests in Redistributive Politics," Journal of Politics 58(4), 1996, pp.1132-1155; Susanne Lohmann, "Federalism and Central Bank Independence: The Politics of German Monetary Policy, 1957-62," World Politics 50(3), 1998, pp.501-546; Brece Bueno de Mesquita, James D. Morrow, Randolph M. Siverson and Alastair Smith, "Political Institutions, Policy Choice and the Survival of Leaders," British Journal of Political Science 32, 2002, pp.559-590. 
abuse of economic policies for short-term electoral gains, and provide a stable policy environment that enhances credibility of governments' commitment to private economic actors. Decentralized decision making allows moderate policies and limits abuse of political power. Multiple veto players provide effective institutional constraints on shifting the costs of inefficient policies to politically unrepresented groups. Alesina and Rosenthal argue that divided government, in which the executive and the legislature are controlled by different parties, is a mechanism for ensuring moderate policies. ${ }^{18)}$

Also, multiple veto player system allows an institutional environment that leads to non-politicized policy making such as delegation of policy authority to technocrats in politically independent agencies. Lohmann explains the central bank independence and its stable monetary policy in Post-WWII Germany as an outcome of constitutional guarantees which required consent of a large number of veto players to revise central bank's status that would be needed to make a change in monetary policy. ${ }^{19)}$ De Figueiredo argues that political uncertainty generated by electoral competition is conducive to delegation of policy authority to technocrats and effective regulatory governance. ${ }^{20)} \mathrm{He}$ contends that electoral volatility generates strong incentives for politicians to insulate legislations made during their tenure by delegating policy authority to independent bureaucratic agencies so that future winners would not be able to revert what they have accomplished. In this vein Hellman, in his study of the economic reform in the postcommunist countries, argues that electoral competition prevents beneficiaries of market reform from sabotaging further progress toward marketization. ${ }^{21)}$ According to him, the main political factor that inhibits greater progression of market reform was the concentration of political power that protects the interests of beneficiaries of "partial reform." He shows that countries, in which ruling parties were vulnerable to greater electoral challenges and executive turnover was frequent, have greater advances in market reform than those that were not.

The brief literature review in this section suggests that theoretically electoral competition and institutional distribution of veto power may work both ways; whether centralized decision making may enhance, or compromise policy performance and economic reform is theoretically open. It is an empirical question which needs to be tested.

18) Alberto Alesina and Howard Rosenthal, Partisan Politics, Divided Government and the Economy (N.Y.: Cambridge University Press, 1995).

19) Lohmann (1998).

20) Rui J. P. Jr. De Figueiredo, "Electoral Competition, Political Uncertainty and Policy Insulation," Institute of Government Studies Working Paper 2001-7, University of California, Berkeley, 2001.

21) Hellman (1998). 


\section{Banking Regulation and Financial Stability}

This section describes some of the ways in which banking regulations influence financial stability or, lack there of. The core role of banking regulation and supervision is to maintain solvency of financial system. Economic literature of financial regulation suggests market failures, i.e., externality and information asymmetries, as the most important reasons for the state's regulation of financial markets. ${ }^{22)}$ Externality refers to the possibility of systemic risks of financial markets arising from the interconnectedness of banks and financial intermediaries. A run on a bank can spread to the entire financial system and lead to systemic banking crisis. Information asymmetries in financial markets lead to "adverse selection" and "moral hazards." Depositors usually do not have sufficient informational resources to distinguish between banks that are well capitalized and the ones that have hidden debts. Without reliable information to tell good banks from bad ones, depositors tend to discount credibility of banks, may demand higher returns on their money than competitive market would provide, and result in adverse selection. ${ }^{23)}$ Also, financial firms may take advantage of superior information to exploit investors. Insider lending is a good example of moral hazards in that lack of information makes depositors vulnerable to exploitation.

Regulators can rely on strict application of internal and external barriers to prevent systemic risks (financial collapse) and problems arising from information asymmetries. They can employ such policy tools as functional segmentation of market sectors, for example, separation of commercial banks from securities, restriction of product choice for financial firms by limiting risky financial instruments like futures or options, and use of licensing system to limit market access only to financial firms with sound record and reputation. By raising barriers along the lines of financial sectors, products and firms, regulators aim at preventing spread of financial failures in one sector to the entire system.

Prudential banking regulations can rely less on restrictive barriers but more on performance standards such as capital adequacy standards and disclosure requirements. Instead of segmenting financial markets, regulators focus on monitoring whether financial market actors abide by regulatory requirements. Regulatory oversight and

22) Charles Goodhart, Philipp Hartmann, David Llewellyn, Liliana Rojas-Suárez and Steve Weibrod, Financial Regulation: Why, How, and Where Now? (London: Routledge, 1998); Joseph E. Stiglitz and Andrew Weiss, "Credit Rationing in markets with Imperfect Information," American Economic Review 71(3), 1981, pp.393-410.

23) Stiglitz and Weiss, Ibid. 
supervision matter because the success of regulation relies heavily on the technical and institutional ability of regulators to monitor. Because of the greater possibility of systemic risks, these regulations are usually accompanied by state provision of an insurance scheme or lender-of-the last-resort facilities against possible bankruptcy and systemic risks.

Distributional implications of implementing prudential regulation are similar to other economic reform policies in the sense that the costs are high in the short term and the benefits are distributed diffusely and realize in the long term. Prudential regulation, if imposed stringently, severely limits profit opportunities of banks and industrial sectors. Prudential regulation imposes an immediate and concentrated opportunity costs on a few actors such as the banks and politicians who benefited from the lax regulatory policies and practices. Also, it has fiscal implication as well if the government has a high volume of liabilities in the private banking sector. Politically, prudential regulation is costly in the sense that it limits an important and politically useful policy tool, i.e., manipulation of bank credit for fiscal and monetary policy purposes. In this respect, institutionalizing a robust system of financial regulation exacts a high level of transaction costs among conflicting political and economic interests. Therefore, financial reform that would strengthen prudential regulation poses a political dilemma to the ruling politicians.

Because of the political costs involved, developing countries usually have compromised in financial regulations; even in the one of the most successful cases of financial reform, Argentina during mid-1990s for example, the Menem government had to compromise on tightening regulations regarding provincial banks. Due to the Argentine electoral system, provincial political leaders exerted effective veto on overhauling the provincial banks because provincial banks serve as an off-budget source of provincial governments' revenue. ${ }^{24)}$ Therefore, how the political compromise regarding financial reform turns out depends on the political transaction cost in domestic politics which in turn is shaped by the patterns of electoral competition and institutional distribution of veto players.

How does financial regulation affect the solvency of banking sector? Systemic stability of financial market is in large part shaped by the nature and quality of national financial regulation given the macroeconomic and international economic environments. The experience of Argentina after the Mexican peso crises in 1995 is a good example

24) Charles W. Calomiris and Andrew Powell, "Can Emerging Market Bank Regulators Establish Credible Discipline? The Case of Argentina, 1992-1999," Working Paper No.14, Central Bank of the Republic of Argentina, Buenos Aires, 2000. 
that attests the importance of regulation for the stability of financial market. While most of Latin American countries suffered heavy loss from the economic shock waves from the Mexican peso crisis, Argentine economy was able to bounce back much more quickly than other countries. The reason lies in the newly strengthened financial regulation under the leadership of Cavallo during the Menem government. ${ }^{25)}$

The differential effect of Asian financial crises in individual countries also demonstrates the critical importance of financial regulation for the stability of national financial system. While it is quite true that the level of exposure to international capital flows was much higher in South Korea, Indonesia and Thailand than in the Philippines and Malaysia, financial exposure was not the only factor that determined the depth of financial meltdown in these countries. The robustness of financial regulation was a major factors that made differences. South Korea's financial regulation was in disarray and its regulatory supervision did not function properly as was the case in Thailand and Indonesia. However, the Philippines and Malaysia had much more tightened and solid system of financial regulation, and their regulatory supervision was much more effective. This difference in banking regulatory governance was an important factor that helped these two countries escape with only minor injuries. ${ }^{26)}$

Regulation changes parameters of other macroeconomic determinants of banking crisis. ${ }^{27)}$ Financial regulation can either mitigate, or aggravate effects of macroeconomic changes on the soundness of banking sector. For example, in the absence of stringent capital adequacy requirements, economic booms spurred by real GDP growth are likely to result in rapid credit growth which would undermine the quality of bank loan portfolio since credit growth would increase volume of high-risk loans. Budget deficits generate strong incentives for the government to use the financial sector as an offbudget source of funding for government objectives by pressuring banks to direct loans to politically favored, often risky, borrowers, which has been quite typical in many developing countries in Asian and Latin America. However, if a robust system of regulation exists, the pressure of budget deficit for inducing imprudent bank lending would be effectively circumscribed.

Prudential regulation would also mitigate the negative effects of interest rate liberalization. In general, interest rate liberalization induces banks to increase deposit

25) Danny M. Leipziger, "The Argentine Banking Crisis: Observations and Lessons," in Gerard Caprio, William C. Hunter, George G. Kaufman and Danny M. Leipziger, (eds.), Preventing Banking Crises: Lessons from Recent Global Bank Failures (Washington D.C.: World Bank, 1998).

26) Shanker Satyanath, "Crossed Signals? Developing Countries and the Liberalizaiton of International Capital Flows," Unpublished Manuscript (New York University, 2002).

27) Keefer (2002). 
rates to attract funds, and thus results in high risk loans that they otherwise would not have extended. This risk-taking behavior of banks would be limited if the regulator do not allow them to engage in risky behaviors. Also, robust banking regulations can mitigate the adverse effects of foreign borrowing by influencing the risk-diversification strategies of banks. Rapid increase in money supply (M2) relative to foreign exchange reserve stemming from massive external borrowing makes domestic financial sector vulnerable to sudden capital outflows and exchange rate devaluation, especially if banks have substantial volume of foreign-currency denominated liabilities. Devaluation would make foreign currency obligations more expensive for banks with significant off-shore exposures. If regulators would have been able to impose risk-diversification on banks and require them to hedge against the exchange rate risks, the consequences of sudden devaluation to Thai banks and Korean merchant banks, which relied heavily on shortterm dollar-denominated loans, would not have been so devastating to the entire financial system in 1997 Asian financial crisis. ${ }^{28)}$

\section{Hypotheses}

I develop two hypotheses that relate political competition variables to the likelihood of banking crisis. The first hypothesis relates institutional distribution of veto players to banking crisis. As the mainstream perspective in the literature of market reform suggests, establishing a robust system of banking regulation would exact a high price from the banking industry and require overhauling of existing, traditional statecontrolled financial regulation. The existence of multiple veto gates would make it tougher to initiate regulatory reform, and the intra-governmental bargaining costs involved in banking reform would be substantial. Therefore, financial intermediaries would be vulnerable to the risk of insolvency to the extent that robust banking regulation is less likely. However, an opposite result would be a possibility as well. As the second strand of literature suggests, in a political system of multiple veto players it would be more difficult for the ruling politicians to manipulate regulatory policies for political purposes. For example, the existence of strong opposition parties in the legislature would make a discretionary bailout of insolvent banks, which is often motivated by political reasons, very costly. To the extent that multiple veto gates work against arbitrary management of banking regulation, the soundness of regulatory

28) Stephan Haggard, "The Politics of the Asian Financial Crisis," Journal of Democracy 11(2), 2000, pp.21-57. 
governance of financial markets would not be compromised.

Hypothesis 1: Veto player As the number of veto players increases, a developing country's ability to establish robust financial regulation would be reduced and accordingly the likelihood of banking crisis would increase.

The second hypothesis concerns the effect of electoral competition on the robustness of banking regulation. As the case of Mexican bank privatization illustrates, heightened electoral challenge from opposition parties might generate strong incentives for the incumbent politicians to abuse financial regulatory policies for electoral gains. Political uncertainty under fierce electoral competition might shorten time horizons of policymakers, and to that extent, short-term political calculus might shape the ways in which financial regulation are managed. Of course, as the second perspective suggests, it is possible that electoral competition might rather enhance robustness of financial regulation, if incumbent politicians delegate regulatory authority to independent agencies so that their political opponents would not be able to abuse regulatory policies upon taking over the government.

Hypothesis 2: Electoral competition As the level of electoral competition increases, a developing country's ability to establish robust financial regulation would be reduced and accordingly the likelihood of banking crisis would increase.

\section{Data and Methodology}

The sample comprises data for 60 developing countries from 1974 to 1997 for which data is available. ${ }^{29)}$ Following previous works such as Demirgüç-Kunt and Detragiache, ${ }^{30}$ I use banking crisis as a proxy measure of the robustness of banking regulation after controlling for the effects of macroeconomic factors and external shocks, and examine

29) The countries in the sample are: Argentina, Burundi, Burkina Faso, Bangladesh, Bolivia, Brazil, Central African Republic, Chile, Cote d' Ivoire, Cameroon, Republic of Congo, Colombia, Cape Verde, Costa Rica, Djibouti, Algeria, Ecuador, Egypt, Eritrea, Ghana, Guinea, Guinea-Bissau, Equatorial Guinea, Indonesia, Israel, Jamaica, Kenya, South Korea, Lebanon, Liberia, Sri Lanka, Morocco, Madagascar, Mexico, Mali, Mozambique, Mauritius, Malaysia, Niger, Nigeria, Nicaragua, Nepal, Panama, Peru, Philippines, Paraguay, Senegal, Sierra Leone, El Salvador, Chad, Togo, Thailand, Turkey, Tanzania, Uganda, Uruguay, Venezuela, Democratic Republic of Congo, Zambia, Zimbabwe.

30) Demirgüç-Kunt and Detragiache (2001). 
how political variables affect the likelihood of outbreak of banking crisis. For this reason, the sample is restricted to those countries about which information on systemic banking crises is available. Also, since there is a good reason to believe that political as well as macroeconomic conditions and institutional environments in developing countries are different from those in advanced countries and former communist countries, I consider banking crises only for developing countries and exclude advanced countries and former communist countries from the sample. Definition and source of the data are available in Table 1, and descriptive statistics contained in Table 2.

$\langle$ Table 1〉 Data Source and Definition

\begin{tabular}{|c|c|c|}
\hline Variable & Definition & Source \\
\hline \multirow[t]{2}{*}{ Banking Crisis } & Systemic banking crisis & Caprio and Kingebiel (2001) \\
\hline & Banking crisis $=1$, no crisis $=0$ & \\
\hline Current Account Balance & $\%$ of GDP & WDI $2000 \mathrm{CD}-\mathrm{ROM}$ \\
\hline Credit to Government & Annual growth as \% if M2 & WDI $2000 \mathrm{CD}-\mathrm{ROM}$ \\
\hline Credit to Private Sector & Annual growth as \% if M2 & WDI 2000 CD-ROM \\
\hline External Debt/GDP & $\%$ of GDP (current) & WDI 2000 CD-ROM \\
\hline Inflation & GDP deflator (annual \%) & WDI 2000 CD-ROM \\
\hline \multirow[t]{2}{*}{$\mathrm{M} 2 / \mathrm{GDP}_{(t-1)}$} & Money and quasi money (M2) & WDI 2000 CD-ROM \\
\hline & as $\%$ of GDP & \\
\hline M2/Reserve(t-1) & M2 to gross international reserves ratio & WDI 2000 CD-ROM \\
\hline Budget(t-1) & Overall budget deficit as \% of GDP & WDI $2000 \mathrm{CD}-\mathrm{ROM}$ \\
\hline Capital Flows/GDP(t-1) & Private capital flows as \% of GDP & WDI 2000 CD-ROM \\
\hline GDP Growth & GDP growth (annual \%) & WDI 2000 CD-ROM \\
\hline GDP per Capita & Real GDP per Capita & Easterly and Sewadeh (2002) \\
\hline Overvaluation & Exchange rate overvaluation & Easterly and Sewadeh (2002) \\
\hline Terms of Trade & Terms of Trade & Easterly and Sewadeh (2002) \\
\hline Economic Openness & Import plus export to GDP ratio & Easterly and Sewadeh (2002) \\
\hline Legislative Competitiveness(t-1) & $\begin{array}{l}\text { Legislative indices of electoral } \\
\text { competitiveness } 1-7 \text { scale }\end{array}$ & Beck et al. (2001) \\
\hline Executive Competitiveness(t-1) & $\begin{array}{l}\text { Legislative indices of electoral } \\
\text { competitiveness } 1-7 \text { scale }\end{array}$ & Beck et al. (2001) \\
\hline Number of Veto Players(t-1) & Number of institutional veto players & Beck et al. (2001) \\
\hline Party Fractionalization $(t-1)$ & $\begin{array}{l}\text { Index of Party system fractionalization } \\
0-1 \text { scale }\end{array}$ & $\begin{array}{l}\text { State Failure Task Force } \\
\text { (N.d.) }\end{array}$ \\
\hline
\end{tabular}




\section{Dependent Variable}

The effect of domestic politics on the financial sector stability is mediated by financial regulations. However, because financial regulation data that would allow cross-section, time series analysis that I intend to conduct in this paper is not available, it is not possible to use variables that measure regulations directly. For this reason, I use banking crisis variable as a proxy for measuring the robustness of banking regulation. Probability of banking crisis is used as a measure of the robustness of banking regulation.

I assume the probability of the outbreak of systemic banking crises as an outcome of national financial regulation after controlling for the effects of macroeconomic and international economic factors. That is, the quality of banking regulation should be consequential to the financial stability of national economy with all other things being equal. Even if a country has a host of adverse macroeconomic conditions such as decline of GDP growth, or exogenous economic shocks such as a sudden reversal of capital flows, national financial system would be much less vulnerable to these adverse factors to the extent that the country's financial regulation is robust and keeps the solvency of banking sector at a higher level than otherwise. This assumption is consistent with empirical evidence in the econometric research literature by economists. For example, examining whether financial liberalization increases the probability of banking crises, Demirgüç-Kunt and Detragiache ${ }^{31)}$ find that banking crises are more likely to occur in countries with a liberalized financial sector where financial liberalization was pursued with weaker institutional environments.

I coded banking crisis data based on the updated version of banking crisis by Caprio and Klingebiel which provides descriptive information on episodes of 113 systemic crises in 93 countries and 50 borderline crises in 44 countries that have occurred since 1970s. ${ }^{32}$ Although there are several other banking crisis lists available such as Glick and Hutchison and Subagjo, the advantage of using information from the list by Caprio and Klingebiel is that it allows a researcher to distinguish systemic from non-systemic banking crises. ${ }^{33)}$

31) Demirgüç-Kunt and Detragiache (2001).

32) Gerard Caprio and Daniela Kingebiel, "Episodes of Systemic and Borderline Financial Crises," Unpublishd manuscript, Washington D.C.: World Bank, 2001.

33) Glick and Hutchison (2000); Murshed and Subagjo (2000). 
〈Table 2〉 Descriptive Statistics

\begin{tabular}{|c|c|c|c|c|c|}
\hline Variable & Obs & Mean & Std. Dev. & Min & $\operatorname{Max}$ \\
\hline Banking Crisis & 1380 & .0557971 & .2296127 & 0 & 1 \\
\hline Current Account Balance & 1173 & -5.756463 & 8.514953 & -132.7956 & 17.51954 \\
\hline Credit to Government & 1273 & 47.89449 & 323.7598 & -5129.681 & 4578.017 \\
\hline Credit to Private Sector & 1264 & 54.89636 & 333.853 & -135.7274 & 7129.181 \\
\hline External Debt/GDP & 1245 & 77.96667 & 88.68199 & 1.9 & 1205 \\
\hline Inflation & 1258 & 90.76067 & 889.7899 & -99.98976 & 26762.35 \\
\hline$M 2 / G D P_{(t-1)}$ & 1190 & 28.15314 & 18.60276 & .8687639 & 171.8451 \\
\hline M2/Reserve(t-1) & 1232 & 11.39356 & 37.66689 & -68.36596 & 829.3021 \\
\hline Budget(t-1) & 881 & -4.35341 & 5.347421 & -31.63226 & 5.413272 \\
\hline Capital Flows/GDP(t-1) & 1195 & .0228997 & .586111 & -.1686038 & 1.414323 \\
\hline GDP Growth & 1250 & 3.336301 & 5.919949 & -42.45112 & 76.0673 \\
\hline GDP per Capita & 1302 & 2202.38 & 1922.975 & 197 & 11209 \\
\hline Overvaluation & 1139 & 124.4532 & 171.763 & 26.04 & 5526.61 \\
\hline Terms of Trade & 1218 & 110.5967 & 35.6165 & 40.28 & 353.34 \\
\hline Economic Openness & 1261 & 57.43134 & 29.09024 & 6.32 & 237.96 \\
\hline Legislative Competitiveness(t-1) & 1292 & 4.70743 & 2.320289 & 1 & 7 \\
\hline Executive Competitiveness $(t-1)$ & 1296 & 4.448688 & 2.192799 & 1 & 7 \\
\hline Number of Veto Players(t-1) & 1291 & 2.012393 & 1.304673 & 1 & 8 \\
\hline Party Fractionalization $(t-1)$ & 1207 & .2984446 & .3157748 & 0 & .9956 \\
\hline
\end{tabular}

Systemic banking crisis refers to cases in which most or all of the national banking system's capital is eroded, and non-systemic "borderline crisis" refers to incidents of bank insolvency for a single or a limited number of financial intermediaries. ${ }^{34)}$ In order to examine the systemic effects of political variables on the outbreak of banking crisis, it is very important to distinguish systemic crisis from non-systemic crisis, because non-systemic crises in general stem from factors specific to individual banks and do not originate from the political or, macroeconomic factors that I consider.

For each country-year in my sample, I construct binary measure of systemic bank crises, as defined above $(1=$ crisis, $0=$ no crisis $)$. Following the empirical works that are concerned with the causes of outbreak of banking crises, ${ }^{35}$ I impose windows on my data

34) Demirgüç-Kunt and Detragiache (2001: 101) identify systemic banking crisis as a situation where one of the following conditions hold: ratio of non-performing assets to total assets is greater than 2 percent of GDP; cost of the rescue operation was at least 2 percent of GDP; banking sector problems resulted in a large scale nationalization of banks; and extensive bank runs took place or emergency measures such as deposit freezes, prolonged bank holidays, or generalized deposit guarantees were enacted by the government in response to the crisis.

35) Glick and Hutchison (2000); Murshed and Subagjo (2000). 
and consider only the onset of crisis, in order to investigate the relationship between political variables and the probability of outbreak of systemic banking crisis. That is, even if banking crises last for more than a year, the year in which the crisis occurred is coded as 1 and the rest of the crisis years are coded as 0 .

\section{Independent Variables}

The political variables that I use to test the hypotheses consist of four separate variables: 'Executive Indices of Electoral Competitiveness' (EIEC), 'Legislative Indices of Electoral Competitiveness' (LIEC), 'CHECK2A' (measure of number of political veto player), and 'Party Fractionalization' (PF). EIEC, LIEC, and CHECK2A come from the 'Database on the Political Institutions' produced by the Development Research Group of World Bank. ${ }^{36)}$ EIEC and LIEC codes the competitiveness of the executive and legislative elections on a scale of 1 to 7. Higher score indicate higher levels of electoral competitiveness. ${ }^{37)}$ CHECK2A codes the number of institutional veto players in a polity. PF come from state failure dataset compiled by State Failure Task Force. ${ }^{38)} \mathrm{PF}$ codes the proportion of members associated with a party in the lower house of the legislature on a scale of 0 to 1 . A higher score on $\mathrm{PF}$ variable indicates greater fragmentation of the party system in a polity.

The two institutional variables, CHECK2A and $\mathrm{PF}$, are used to test the first hypothesis regarding distribution of veto player, and the two electoral variables, EIEC and LIEC, are used to test the second hypothesis regarding electoral competition. Since the effects of institutional variables on the financial regulation and the probability of banking crisis are not immediate, but materialize after a certain period of time, I lagged all the independent variables in the model by one year.

\section{Control Variables}

In addition to the electoral and institutional variables, I also include a number of

36) Thorsten Beck, George Clarke, Alberto Groff, Philip Keefer and Patrick Walsh, "New Tools and New Tests in Comparative Political Economy: The Database of Political Institutions Version 3.0." Manuscript, World Bank Development Research Group, 2001.

37) The scale for EIEC and LIEC variable is determined as follows: No legislature: 1; Unelected legislature: 2; Elected, 1 candidate: 3; 1 party, multiple candidates: 4; multiple parties are legal but only one party won seats: 5 ; multiple parties did win seats but the largest party received more than 75\% of the seats: 6 ; largest party got less than 75\%: 7 .

38) State Failure Task Force. N.D. State Failure Dataset Cambridge, Mass.: University Press. Available at http://gking.harvard.edu/. 
macroeconomic and international economic variables that are found to be theoretically and empirically important for the outbreak of banking crisis in the economic literature: current account balance, credit to the government sector, credit to the private sector, external debt, inflation, money supply (M2), money supply relative to international reserves, budget deficit, capital flows, GDP growth, GDP per capita, exchange rate overvaluation, terms of trade, economic openness. ${ }^{39)}$

\section{Methødølogy}

For the purpose of statistical modelling, I assume financial regulation across countries over time as unobservable and treat banking regulation as a latent variable. ${ }^{40)}$ The latent banking regulation, $y^{*}$ is assumed to be influenced by the observed political and economic variables, $x$ 's, through the structural model:

$$
y^{*}{ }_{i t}=\chi_{i t} \beta+\varepsilon_{i t}
$$

$y^{*}{ }_{i t}$ refers to banking regulation of a country, $i$, in a year, $t$, and $x_{i t}$ represents a vector of political and economic variables that influence banking regulation. I assume that a crisis occurs if the quality of banking regulation of a country in a given year deteriorates below a certain level $(\tau)$. The symbol, $\tau$, represents a threshold for the quality of banking regulation. If the quality of banking regulation of a country in a given year is below the threshold, $\tau$, it is likely that we observe an occurrence of a banking crisis. If the quality of banking regulation is above the threshold, then we assume that no crisis occurs.

$$
y_{i t}=\left\{\begin{array}{l}
0 \text { if } y^{*}>\tau \\
1 \text { if } y^{*} \leq \tau
\end{array}\right.
$$

$y_{i t}$ refers to an observable binary variable for banking crisis. if $y_{i t}=1$, we have a crisis, and if $y_{i t}=0$, then we have no crisis. Note that by the assumption of the model, $y_{i t}=0$

39) Control variables are extracted from World Bank, World Development Indicator CD-ROM (Washington D.C.: World Bank, 2000) and William Easterly and Mirvat Sewadeh, Global Development Network Growth Database. Available at http://www.worldbank.org/research/growth/GDNdata.htm. The definition and source of the control variables are in Table 1.

40) For the statistical justification of a logistic regression based on a latent variable model, see Scott J. Long, Regression Models for Categorical and Limited Dependent Variables (Thousand Oaks, Ca.: Sage, 1997). 
only if $y^{*}{ }_{i t}>\tau$ and $y_{i t}=1$ only if. $y^{*}{ }_{i t} \leq \tau$. Based on these assumptions, the model I will estimate is:

$$
\operatorname{Probability}\left(y_{i t}\right)=F\left(\Sigma \beta_{j} P O L_{j i(t-1)}+\Sigma \beta_{k} E C O N_{k i t}\right)
$$

In this way, we can regard the probability of a banking crisis of a country in a given year as a measure of financial stability (or frailty) that would serve as a proxy measure of the quality of banking regulation given the macroeconomic and external economic factors.

Since the dependent variable is a binary variable that measures outbreak of banking crises, it is necessary to use a limited dependent variable estimation method. However, an ordinary logit or probit analysis can produce biased estimates when the observations are "rare events" in the sample."1) The data shows that banking crisis occurs less than $6 \%$ of the time in the sample. To address this concern, I use a rare events logit estimator utility program for STATA, relogit, written by Tomz, King and Zeng. ${ }^{42)}$

Another problem that encounters an empirical analysis of the binary panel data like banking crisis variable is temporal dependence that violates the assumption that observations are independent. Beck, Katz and Tucker ${ }^{43)}$ show that binary panel data are "grouped duration data" and that the results of an ordinary or probit analysis may lead to severe inefficiency in the estimation in the existence of temporal dependence. ${ }^{44)}$ Although I imposed windows on the banking crisis data and considering only the onset of crisis, it does not fully address potential problem of temporal dependence in the data. The incident of banking insolvencies of a country may be related to the length of time since the last banking crisis given the lasting consequences of a systemic banking crisis for domestic financial system. Beck, Katz and Tucker suggest that the problem of temporal dependence can be resolved by including a set of dummy variables in the model that take into account of the length of time since the country's last 'failure. ${ }^{45)}$ They

41) Gary King and Langche Zeng, "Explaining Rare Events in International Relations," International Organization 55(3), 2001, pp.693-715; Gary King and Langche Zeng, "Logistic Regression in Rare Events Data," Political Analysis 9(2), 2001, pp.137-163.

42) Michael Tomz, Gary King and Langche Zeng, ReLogit: Rare Events Logistic Regression Version 1.1 (Cambridge, Mass.: Harvard University, 1999). Available at http://gking.harvard.edu/.

43) Nathaniel Beck, Jonathan N. Katz and Richard Tucker, "Taking Time Seriously: Times SeriesCross-Section Analysis with a Binary Dependent Variable," American Journal of Political Science 42(4), 1998, pp.1260-1288.

44) If the hazard rate is time variant, that is, the risk of 'failure' depends on how long a unit has survived, the hazard rate is said to be "duration dependent" (Beck, Katz and Tucker 1998, 1264).

45) Beck, Katz and Tucker, Ibid. 
recommend using a set of cubic splines that fit a smooth function to the time dummies in cases of a large number of time periods. The set of cubic splines can be interpreted as indicating whether the length of time since the last banking crisis makes a country more or less likely to be at risk to experiencing a banking crisis. I created and included a set of three natural cubic splines to my data, using a utility program for STATA, btscs, written by Tucker. ${ }^{46)}$

\section{Results}

The first column in Table 3 is a baseline model that includes economic variables that are found to be theoretically important for the outbreak of banking crisis. The estimated results are generally in line with prior findings in the economic literature. Most variables identified by economic literature are statistically significant and in the expected direction. Increase in the credit to the government sector, borrowing more money from abroad, expansion of domestic money supply relative to the international reserves, and massive capital inflows all contribute to the deterioration of the quality of banking loan portfolios, and make the probability of a systemic banking crisis more likely. However, current account balance, credit to private sector, inflation, money supply to domestic economy (M2), GDP per capita, government budget defict, overvaluation, and changes in terms of trade turn out to be insignificant.

Increase in external debt is positively related to the likelihood of banking crisis, and it is statistically significant at 5\% level. The coefficient is close to zero, though. 1 percent increase in external debt as a ratio of GDP increases about $0.3 \%$ increase in the probability of banking crisis. Growth of money supply relative to international reserves is statistically significant and is positively related with the probability of banking crisis. As expected, the table shows that capital inflows exert a large impact on the financial vulnerability. Capital inflows have a strong positive influence on the probability of banking crisis after one year. Given the fact that many of banking crisis in developing world occurred after external financial liberalization and massive inflow of capital flows, it is quite an expected result. Also, national economic performance measured as GDP growth is statistically significant; it is negatively associated with banking crisis. This result confirms the expectation that economic decline in the business cycle is a contributing factor to the deterioration of loan portfolio and insolvency risks of banks.

46) Richard Tucker, BTSCS: A Binary Time-Series Cross-Section Data Analysis Utility Version 4.0.4 (Cambridge, Mass.: Harvard University, 1999). Available at http://gking.harvard.edu/. 
〈Table 3〉 Logit Estimates I

\begin{tabular}{|c|c|c|c|c|c|}
\hline Variable & $\begin{array}{c}\text { Business } \\
\text { Model } 1\end{array}$ & $\begin{array}{c}\text { Electoral (Leg.) } \\
\text { Model } 2\end{array}$ & $\begin{array}{c}\text { Electoral (Exec.) } \\
\text { Model } 2\end{array}$ & $\begin{array}{c}\text { Party Frag. } \\
\text { Model } 4 \\
\end{array}$ & $\begin{array}{l}\text { Vet॰ Player } \\
\text { Mødel } 5 \\
\end{array}$ \\
\hline \multirow[t]{2}{*}{ Current Acc./GDP } & 0.008 & 0.008 & 0.009 & 0.006 & 0.008 \\
\hline & $(0.32)$ & $(0.031)$ & $(0.031)$ & $(0.035)$ & $(0.032)$ \\
\hline \multirow[t]{2}{*}{ Credit to Government } & $0.0007^{* *}$ & $0.0008 *$ & $0.0008 * *$ & $0.0006 * *$ & $0.0007^{* *}$ \\
\hline & $(0.0003)$ & $(0.0004)$ & $(0.0003)$ & $(0.0003)$ & $(0.0004)$ \\
\hline \multirow[t]{2}{*}{ Credit to Private } & -0.00 & -0.00 & -0.00 & -0.00 & -0.00 \\
\hline & $(0.0004)$ & $(0.0004)$ & $(0.0004)$ & $(0.0003)$ & $(0.0004)$ \\
\hline \multirow[t]{2}{*}{ External Debt/GDP } & $0.003^{*}$ & $0.004 *$ & $0.004^{*}$ & $0.005^{* *}$ & $0.003^{*}$ \\
\hline & $(0.002)$ & $(0.002)$ & $(0.002)$ & $(0.002)$ & $(0.002)$ \\
\hline \multirow[t]{2}{*}{ Inflation } & -0.00 & -0.00 & -0.00 & -0.00 & -0.00 \\
\hline & $(0.0001)$ & $(0.0001)$ & $(0.0001)$ & $(0.0001)$ & $(0.0001)$ \\
\hline \multirow[t]{2}{*}{$\mathrm{M} 2 / \mathrm{GDP}_{(t-1)}$} & 0.007 & 0.012 & 0.008 & 0.003 & 0.008 \\
\hline & $(0.013)$ & $(0.013)$ & $(0.012)$ & $(0.012)$ & $(0.014)$ \\
\hline \multirow[t]{2}{*}{ M2/Reserve(t-1) } & $0.018^{* * *}$ & $0.012 * * *$ & $0.017 * * *$ & $0.017 * * *$ & $0.018 * * *$ \\
\hline & $(0.005)$ & $(0.004)$ & $(0.004)$ & $(0.004)$ & $(0.004)$ \\
\hline \multirow[t]{2}{*}{ Budget/GDP $P_{(t-1)}$} & 0.032 & 0.032 & 0.031 & 0.026 & 0.034 \\
\hline & $(0.039)$ & $(0.037)$ & $(0.039)$ & $(0.044)$ & $(0.04)$ \\
\hline \multirow[t]{2}{*}{ Capital Flows/GDP(t-1) } & $12.48 * *$ & $10.78^{* *}$ & $10.75^{*}$ & $12.54^{*}$ & $12.23 * *$ \\
\hline & $(5.44)$ & $(5.45)$ & $(5.53)$ & $(6.76)$ & $(5.41)$ \\
\hline \multirow[t]{2}{*}{ GDP Growth } & $-0.088 * * *$ & $-0.094 * * *$ & $-0.093 * * *$ & $-0.074 * * *$ & $-0.088 * * *$ \\
\hline & $(0.029)$ & $(0.031)$ & $(0.029)$ & $(0.028)$ & $(0.028)$ \\
\hline \multirow[t]{2}{*}{ CDP per Capita } & 0.00 & 0.00 & 0.00 & 0.00 & 0.00 \\
\hline & $(0.0001)$ & $(0.0001)$ & $(0.0001)$ & $(0.0001)$ & $(0.0001)$ \\
\hline \multirow[t]{2}{*}{ Overvaluation } & 0.001 & 0.00 & 0.001 & 0.00 & 0.001 \\
\hline & $(0.003)$ & $(0.004)$ & $(0.003)$ & $(0.003)$ & $(0.003)$ \\
\hline \multirow[t]{2}{*}{ Terms of Trade } & 0.005 & 0.004 & 0.004 & 0.004 & 0.004 \\
\hline & $(0.007)$ & $(0.006)$ & $(0.007)$ & $(0.007)$ & $(0.007)$ \\
\hline \multirow[t]{2}{*}{ Economic Openness } & $-0.021^{* *}$ & $-0.021^{* *}$ & $-0.02^{* *}$ & $-0.028 * *$ & $-0.02^{* *}$ \\
\hline & $(0.009)$ & $(0.009)$ & $(0.009)$ & $(0.012)$ & $(0.009)$ \\
\hline Legislative Comp.(t-1) $_{(1)}$ & & $\begin{array}{r}-0.18^{* *} \\
(0.075)\end{array}$ & & & \\
\hline Executive Comp.(1-1) & & & $\begin{array}{l}-0.17^{*} \\
(0.093)\end{array}$ & & \\
\hline \multirow[t]{2}{*}{ Party Fract.(t-1) } & & & & -.36 & \\
\hline & & & & $(0.66)$ & \\
\hline \multirow[t]{2}{*}{ No. of Veto Players.(t-1) } & & & & & 0.062 \\
\hline & & & & & $(0.18)$ \\
\hline Observations & 718 & 716 & 718 & 690 & 715 \\
\hline
\end{tabular}

Estimates obtained by rare events logit estimator via relogit command by Tomz, King and Zeng (1999) in STATA 6.0 version.

Logit esimates on a set of natural cubic spliness included in the model are not reported.

Robust Standard Errors are in the parentheses

*significant at $10 \%$; *significant $1 \mathrm{t} 5 \%$; ***significant at $1 \%$ 
$\langle$ Table 4〉 Logit Estimates II

\begin{tabular}{|c|c|c|c|c|}
\hline Variable & $\begin{array}{c}\text { Electoral (Leg.) } \\
\text { / Veto } \\
\text { Model } 6\end{array}$ & $\begin{array}{c}\text { Electoral (Exec.) } \\
\text { / Veto } \\
\text { Model } 7\end{array}$ & $\begin{array}{l}\text { Electoral (Leg.) } \\
\text { / party Frag. } \\
\text { Model } 8 \\
\end{array}$ & $\begin{array}{c}\text { Electoral (exec.) } \\
\text { / Party Frag. } \\
\text { Model } 9\end{array}$ \\
\hline \multirow[t]{2}{*}{ Current Acc./GDP } & 0.007 & 0.008 & 0.005 & 0.007 \\
\hline & $(0.32)$ & $(0.032)$ & $(0.034)$ & $(0.034)$ \\
\hline \multirow[t]{2}{*}{ Credit to Govt. } & $0.0007 * *$ & $0.0007^{*}$ & $0.0008 * *$ & $0.0007 * *$ \\
\hline & $(0.0003)$ & $(0.0004)$ & $(0.0004)$ & $(0.0004)$ \\
\hline \multirow[t]{2}{*}{ Credit to Private } & -0.00 & -0.00 & -0.00 & -0.00 \\
\hline & $(0.0004)$ & $(0.0004)$ & $(0.0004)$ & (0.0003) \\
\hline \multirow[t]{2}{*}{ External Debt/GDP } & $0.004 *$ & $0.004^{*}$ & $0.005^{*}$ & $0.005^{* *}$ \\
\hline & $(0.001)$ & $(0.002)$ & $(0.002)$ & $(0.002)$ \\
\hline \multirow[t]{2}{*}{ Inflation } & -0.00 & -0.00 & -0.00 & -0.00 \\
\hline & $(0.0001)$ & $(0.0001)$ & $(0.0001)$ & $(0.0001)$ \\
\hline \multirow{2}{*}{ M2/GDP $P_{(t-1)}$} & 0.009 & 0.004 & 0.002 & 0.0008 \\
\hline & $(0.013)$ & $(0.012)$ & $(0.012)$ & $(0.011)$ \\
\hline \multirow[t]{2}{*}{ M2/Reserve(t-1) } & $0.019 * * *$ & $0.018 * * *$ & $0.018 * * *$ & $0.016 * * *$ \\
\hline & $(0.005)$ & $(0.005)$ & $(0.004)$ & $(0.004)$ \\
\hline \multirow[t]{2}{*}{ Budget/GDP(t-1) } & 0.028 & 0.025 & 0.015 & 0.018 \\
\hline & $(0.037)$ & (0.039) & $(0.041)$ & $(0.043)$ \\
\hline \multirow[t]{2}{*}{ Capital Flows/GDP(t-1) } & $10.96^{* *}$ & $10.60 * *$ & 10.35 & 10.57 \\
\hline & $(5.47)$ & $(5.54)$ & $(6.72)$ & $(6.89)$ \\
\hline \multirow[t]{2}{*}{ GDP Growth } & $-0.091^{* * *}$ & $-0.089 * * *$ & $-0.08 * * *$ & $-0.079^{* * *}$ \\
\hline & $(0.03)$ & $(0.029)$ & $(0.03)$ & $(0.029)$ \\
\hline \multirow[t]{2}{*}{ CDP per Capita } & 0.00 & 0.00 & 0.00 & 0.00 \\
\hline & $(0.0001)$ & $(0.0001)$ & $(0.0001)$ & $(0.0001)$ \\
\hline \multirow[t]{2}{*}{ Overvaluation } & 0.00 & 0.00 & 0.001 & 0.00 \\
\hline & $(0.004)$ & $(0.003)$ & $(0.003)$ & $(0.003)$ \\
\hline \multirow[t]{2}{*}{ Terms of Trade } & 0.004 & 0.003 & 0.003 & 0.003 \\
\hline & $(0.007)$ & $(0.007)$ & $(0.007)$ & $(0.007)$ \\
\hline \multirow{2}{*}{ Economic Openness } & $-0.023 * *$ & $-0.021^{* *}$ & $-0.027 * *$ & $-0.026 * *$ \\
\hline & $(0.009)$ & $(0.009)$ & $(0.012)$ & $(0.012)$ \\
\hline \multirow[t]{2}{*}{ Legislative Comp.(t-1) } & $-0.24 * * *$ & & $-0.23^{* *}$ & \\
\hline & $(0.095)$ & & $(0.1)$ & \\
\hline \multirow[t]{2}{*}{ Executive Comp.(t-1) } & & -0.26 & & -0.187 \\
\hline & & $(0.16)$ & & $(0.12)$ \\
\hline \multirow[t]{2}{*}{ Party Fract.(t-1) } & & & 0.79 & 0.33 \\
\hline & & & $(0.72)$ & $(0.69)$ \\
\hline \multirow[t]{2}{*}{ No. of Veto Players.(1-1) } & 0.18 & 0.23 & & \\
\hline & $(0.18)$ & (0.16) & & \\
\hline Observations & 715 & 715 & 688 & 690 \\
\hline
\end{tabular}

Estimates obtained by rare events logit estimator via relogit command by Tomz, King and Zeng (1999) in STATA 6.0 version.

Logit estimates on a set of natural cubic spliness included in the model are not reported.

Robust Standard Errors are in the parentheses

*significant at 10\%; ** significant 1t 5\%; *** significant at $1 \%$ 
Results from testing the two hypotheses relating political variables to banking crisis are reported in columns 2 through 5 in Table 3 and Table 4. Hypothesis 1 focuses on the relationship between veto players and banking crisis. The number of institutional veto players and party fragmentation variables were used to test this hypothesis. The estimation result fails to confirm the hypothesis. While the number of veto players and party fragmentation are negatively associated with the probability of banking crisis, this effect is not statistically significant.

However, the result shows statistically significant evidence regarding the second hypothesis. Hypothesis 2 concerns the relationship between electoral competition and the likelihood of banking crisis. Two variables, the executive and legislature electoral competition, were used to test the hypothesis. The estimation result negates hypothesis 2 with statistical significance. Estimation shows that the probability of banking crisis decreases as the degree of electoral competition increases. Legislative as well electoral competition is negatively associated with banking crisis, and the relationship is statistically significant. This result holds under different specifications of models as shown in Table 4. This disconfirms the second hypothesis that expected a positive relationship between electoral competition and probability of banking crisis.

\section{〈Figure 2〉 Effects of legislative electoral competition on banking crisis}

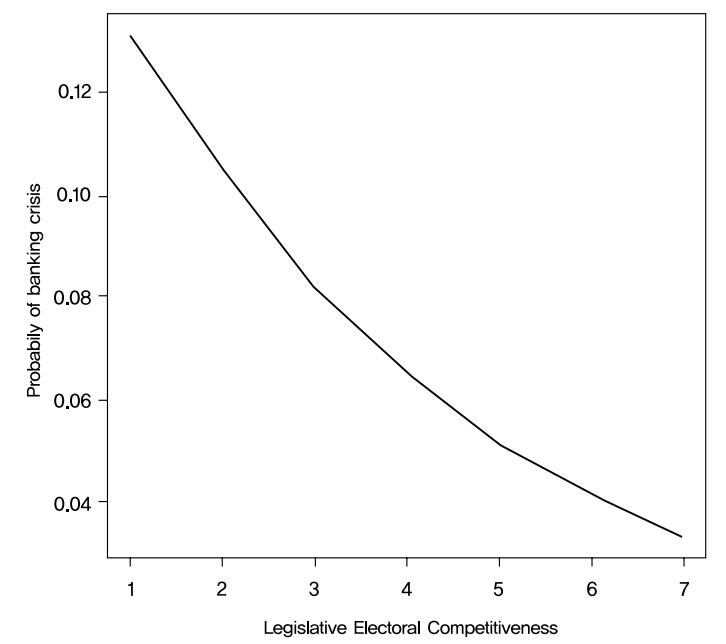

Note: The values of all other variables are set at their median.

One unit increase in the scale of legislative electoral competitiveness index results about $16 \%$ to $21 \%$ decrease in the probability of banking crisis with the values of all other variables fixed. Executive electoral competitiveness index shows similar result, 
about $16 \%$ to $23 \%$ decrease in the probability of banking crisis for a one unit change in the electoral competition scale. To get a visual picture of the relationship between the electoral competition and banking crisis, I plot a simulated relationship between the legislative electoral competition and the probability of banking crisis based on the estimation results. Figure 2 shows a clear negative relationship between likelihood of banking crisis and the electoral competition. The estimated probability of banking crisis would be about $13.2 \%$ when the electoral competitiveness index is 1 , and about $3 \%$ when the index is 7.

The estimation results are consistent with expectation of the theoretical perspectives that predicted a positive relationship of electoral competition with policy performance and economic reform. ${ }^{47)}$ The theoretical implications of this result are clear. First, competitive political environment limits politicians' discretionary manipulation of financial policies that would ultimately undermine systemic stability of national financial markets. Rather than shortening time horizons of policy makers, competitive electoral pressure seems more likely to constrain incumbent politicians' ability to abuse financial regulatory policies for electoral purposes.

Second, as the case study literature of financial crises of developing countries shows, weakening of banking solvency is often associated with prevalence of extensive practices of regulatory forbearance. ${ }^{48)}$ Regulatory forbearance is a politically useful policy tool to support political allies and important electoral constituents in the governing coalition. The result suggests the existence of a connection between electoral constraints, or lack there of, and the prevalence of regulatory forbearance. Lack of electoral constraints on the incumbent politicians is an important political factor that contributes to the prevalence of regulatory forbearance in developing world. To the extent that electoral constraints do not exist or are not strong enough to reduce the incumbent politicians's reliance on regulatory forbearance, the incumbent politicians are not likely to eliminate regulatory forbearance.

Although the causal mechanism of how electoral competition influences financial regulatory governance needs further clarification with case studies on individual developing country's financial regulatory reform episode, the empirical evidence produced in this paper implies the importance of competitive political environment for developing countries's ability to maintain a system of robust regulatory governance that is crucial in keeping financial markets stable.

47) De Figueiredo (2001); Hellman (1998); Bueno de Mesquita et al.(2002).

48) Noble and Ravenhill (2000); Haggard and MacIntyre (2000); Brownbridge and Kirkpatrick (2000); Haggard (2000b). 


\section{Concluding Remarks}

In this paper I attempted to uncover the causal relationship between domestic politics and robustness of banking regulation (and financial stability) in the developing world by focusing on the role of electoral competition and institutional distribution of political veto players. The theoretical expectation about the role of these political variables in shaping financial regulation in the literature is ambiguous. On the one hand, some scholars argue that centralized decision making would be conducive for effective policy outcomes and market reform. The prediction from this perspective is a positive relationship between centralization and robust banking regulation and financial stability in developing world. On the other hand, others suggest an opposite argument, contending that it is decentralization that is more facilitative for policy performance and market reform. The extension of this perspective to banking regulation would be a negative relationship between centralization and financial regulation.

By conducting a statistical investigation of these two contending perspectives on a sample of 60 developing countries, I aimed at producing empirical evidence that would help resolve the debate. My research results in this paper suggest that electoral competition is a statistically important factor that improves the robustness of banking regulation and reduces the probability of banking crises in the developing world. However, I do not find statistically significant evidence regarding the role of distribution of institutional veto players and party fragmentation.

The finding in this paper suggests important empirical evidence about the relationship between electoral competition and banking regulations in developing world. It poses further questions for future research, however. The precise causal role of electoral competition in shaping banking regulation is still unclear. Especially, the question of how electoral competition influences policy profiles and institutional arrangements of banking regulation needs further investigation. Questions regarding the institutional form of financial regulation, for example, delegation of regulatory authority to an independent agency, that would provide a stable institutional environment for robust regulatory governance, beg further investigation. Answers to these questions would bear important implications for the design of effective regulatory system in the developing world. 


\section{REFERENCES}

Alesina, Aberto and Allan Drazen, 1998. "Why are Stabilization Delayed?" in Federico Sturzenegger and Mariano Tommasi (eds.), The Political Economy of Reform Cambridge, Mass: The MIT Press, pp.77-103.

Alesina, Alberto and Howard Rosenthal, 1995. Partisan Politics, Divided Government and the Economy N.Y.: Cambridge University Press, 1995.

Alesina, Alberto and Nouriel Roubini with Gerald D. Cohen. 1999. Political Cycles and the Macroeconomy Cambridge, Mass: The MIT Press, 1999.

Beck, Nathaniel, Jonathan N. Katz and Richard Tucker. 1998. "Taking Time Seriously: Times Series-Cross-Section Analysis with a Binary Dependent Variable," American Journal of Political Science 42(4), pp.1260-1288.

Beck, Thorsten, George Clarke, Alberto Groff, Philip Keefer and Patrick Walsh. 2001.

"New Tools and New Tests in Comparative Political Economy: The Database of Political Institutions Version 3.0.” Manuscript, World Bank Development Research Group.

Bernhard, William and David Leblang. 1999. "Democratic Institutions and ExchangeRate Commitments," International Organization, 53(1).

Brownbridge, Martin and Colin Kirkpatrick. 2000. "Financial Regulation in Developing Countries," Journal of Developmental Studies, 37(1), pp.1-24.

Bueno de Mesquita, Brece, James D. Morrow, Randolph M. Siverson and Alastair Smith, "Political Institutions, Policy Choice and the Survival of Leaders. 2002." British Journal of Political Science 32, pp.559-590.

Calomris, Charles W. and Andrew Powell. 2000. "Can Emerging Market Bank Regulators Establish Credible Discipline? The case of Argentina, 1992-1999," Working Paper No.14, Buenos Aires: Central Bank of the Republic of Argentina.

Caprio, Gerard and Daniela Kingebiel. 1996. "Bank Insolvencies: Cross-country Experiences," World Bank, World Bank Policy Research Paper 1620, Washington D.C.: World Bank Research Paper 1620.

Carpio Gerard and Daniela Kingebiel. 2001. "Episodes of Systemic and Borderline Financial Crises," Unpublished manuscript, World Bank, Washington D.C.

De Figueiredo, Rui J. P. Jr. 2001. "Electoral Competition, Political Uncertainty and Policy Insulation," Institute of Government Studies Working paper 2001-7, Berkeley Ca.: University of California, Berkeley. 
Demirgüç-Kunt, Asli and Enrica Detragiache. 2001. "Financial Liberalization and Financial Fragility" in Caprio Gerard, Parick Honohan and Joseph E. Stiglitz (eds.), Financial Liberalization: How Far, How Fast? N.Y.: Cambridge University Press, pp.96-122.

Dixit, Avinash and John Londregan. 1995. "Redistributive Politics and Economic Efficiency," American Political Science Review 89(4), pp.856-866

Dixit, Avinash and John Londregan. 1996. "The Determinants of Success of Special Interests in Redistributive Politics," Journal of Politics 58(4), pp.1132-1155

Easterly, William and Mirvat Sewadeh. 2002. Global Development Network Growth Database Washington D.C.: World Bank

(Available at http://www. worldbank.org/research/growth/GDNdata.htm).

Eichengreen, Barry and Carlos Arteta. 2002. "Banking Crises in Emerging Markets: Presumptions and Evidence," in Mario I. Blejer and Marko Skreb (eds.) Financial Policies in Emerging Markets Cambridge, Mass.: The MIT Press, pp.47-94.

Fernández Raquel and Dani Rodrik. 1998. "Resistance to Reform : Status Quo Bias in the Presence of Individual-Specific Uncertainty," in Federico Stuzenegger and Mariano Tommasi (eds.), The Political Economy of Reform Cambridge, Mass.: The MIT Press, pp.61-76.

Garrett, Geoffrey and Peter Lange. 1996. "Internationalization, Institutions and Political Change," in Robert O. Keohane and Helen V. Milner (eds.), Internationalization and Domestic Politics N.Y.: Cambridge University Press, pp.48-55.

Glick, Reuven and Michael Hutchison. 2000. "Banking and Currency Crises: How Common Are Twins?” Unpublished manuscript, Santa Cruz: Federal Reserve Bank of San Francisco and University of California.

Goodhart, Charles, Philipp Hartmann, David Llewellyn, Liliana Rojas-Suárez and Steve Weibrod. 1998. Financial Regulation: Why, How, and Where Now? London: Routledge.

Gourevitch, Peter. 1996. "Squaring the Circle: The Domestic Sources of International Cooperation," International Organization 50(2), pp.349-373.

Haggard, Stephan. 2000a, "Interests, Institutions and Policy Reform," in Ann O. Krueger (ed.), Economic Policy Reform: The Second Stage Chicago: University of Chicago Press, pp.21-57.

Haggard, Stephan. 2000b, The Political Economy of Asian Financial Crisis Washington D.C.: Institute for International Economics. 
Haggard, Stephan. 2000c, "The Politics of the Asian Financial Crisis," Journal of Democracy 11(2), pp.21-57.

Hagard, Stephan and Adrew MacIntyre. 2000. "The Political Economy of the Asian Financial Crisis: Korea and Thailand Compared," Gregory W. Noble and John Ravenhill, (eds), The Asian Financial Crisis and the Architecture of Global Finance New York: Cambridge University Press.

Haggard, Stephan and Rober R. Kaufman. 1989. "Economic Adjustment in New Democracies," in Joan M. Nelson (ed.), Fragile Coalitions: The Politics of Economic Adjustment Washington. D.C.: Overseas Development Council, pp.57-77.

Haggard, Stephan and Robert R. Kaufman. 1995. The Political Economy of Democratic Transitions Princeton: Princeton University Press.

Hallerberg, Mark. 2002. "Veto Players and the Choice of Monetary Institutions," International Organization, 56(4), pp.775-802.

Hellman, Joel S. 1998. "Winners Take All: The Politics of Partial Reform in Postcommunist Transitions," World Politics 50(2), pp.203-234.

Keefer, Philip. 2002. "Politics and the Determinants of Banking Crisis: The Effects of Political Checks and Balances" Leonardo Hernandez and Klaus Schmidt-Hebbel (eds.), Financial Integration and International Crisis Santiago: Central Bank of Chile, pp.85-112.

Keefer, Philip and David Stasavage. 2002. "Checks and Balances, Private Information and the Credibility of Monetary Commitments," International Organization, 56 (4), pp.751-774

Kessler, Timothy P. 1998. "Political Capital: Mexican Financial Policy under Salinas," Word Politics 51(1), pp.36-66.

King, Gary and Langche Zeng. 2001a, "Explaining Rare Events in International Relations," International Organization 55(3), pp.693-715.

King, Gary and Langche Zeng. 2001b. "Logistic Regression in Rare Events Data," Political Analysis 9(2), pp.137-163.

Leblang, David A. 2002. "The Political Economy of Speculative Attacks in the Developing World," International Studies Quarterly, 46, pp.69-91.

Leipziger, Danny M. 1998. "The Argentine Banking Crisis: Observations and Lessons," in Gerard Caprio, William C. Hunter, George G. Kaufman and Danny M. Leipziger (eds.), Preventing Banking Crises: Lessons from Recent Global Bank Failures Washington D.C.: World Bank. 
Lohmann, Susanne. 1998. "Federalism and Central Bank Independence: The Politics of German Monetary Policy, 1957-62," World Politics 50(3), pp.501-546

Long, Scott J. 1997. Regression Models for Categorical and Limited Dependent Variables Thousand Oaks, Ca.: Sage.

MacIntyre, Andrew. 2001. "Institutions and Investors: The Politics of Economic Crisis in Southeast Asia," International Organization, 55(1), pp.81-122.

Murshed, S. Mansoob and Djono Subagjo. 2000. "Prudential Regulation of Banks in Less Developed Economies," World Institute for Development Economics Research, Working Paper No.1999, United Nations University.

Nelson, Joan M. 1993. "The Politics of Economic Transformation: Is Third World Experience Relevant in Eastern Europe?" World Politics 45(3), pp.433-463.

Noble, Gregory W. and John Ravenhill, (eds.) 2000. The Asian Financial Crisis and the Architecture of Global Finance N.Y.: Cambridge, Mass.: Harvard University Press.

Olson, Mancur. 1965. The Logic of Collective Action Cambridge, Mass: Harvard University Press.

Pempel, T. J. (ed) 1999. The Politics of the Asian Economic Crisis Ithaca: Cornell University Press.

Przeworski, Adam. 1991. Democracy and the Market: Political and Economic Reforms in Eastern Europe N.Y.: Cambridge University Press.

Rojas-Suárez, Liliana and Steven R. Weisbrod. 1996. "Banking Crises in Latin America: Experiences and Issues,” in Ricardo Hausman and Liliana Rojas-Suárez (eds.), Banking Crises in Latin America Washington D.C.: Inter-American Development Bank.

Satyanath, Shanker. 2002. "Crossed Signals? Developing Countries and the Liberalization of International Capital Flows," Unpublished Manuscript, New York University.

Skidmore, Thomas. 1977. "The Politics of Stabilization in Postwar Latin America," in James Malloy (ed.), Authoritarianism and Corporatism in Latin America Pittsburgh: University of Pittsburgh Press.

State Failure Task Force. N.D. State Failure Dataset Cambridge, Mass.: Harvard University Press. (Available at http://gking.harvard.edu/)

Stiglitz, Joseph E. and Andrew Weiss. 1981. "Credit Rationing in Markets with Imperfect Information," American Economic Review 71(3), pp.393-410.

Tommasi, Mariano and Andrés Velasco. 1996. "Where Are We in the Political Economy of Policy Reform,” Policy Reform 1, pp.187-238. 
Tomz, Michael, Gary King and Langche Zeng. 1999. ReLogit: Rare Events Logistic Regression Version 1.1 Cambridge, Mass.: Harvard University. (Available at http://gking.harvard.edu/).

Tucker, Richard. 1999., BTSCS: A Binary Time-Series Cross-Section Data Analysis Utility. Version 4.0.4 Cambridge, Mass.: Harvard University. (Available at http://www.vanderbilt.edu/rtucker/programs/btscs).

World Bank. 2000. World Development Indicator CD-ROM Washington D.C.: World Bank. 